\title{
China as a Strategic Economic Partner in the Concepts of Russian Foreign Policy in the 2020s'
}

\section{China as a Strategic Economic Partner in the Concepts of Russian Foreign Policy in the 2020s}

\section{Abstract}

The article presents an idea of the possible Russian - Chinese strategic economic partnership at the beginning of the $21^{\text {st }}$ century. The author indicates the main factors influencing Russian Federation foreign policy towards China from the perspective of a neoclassical realism. The author stands that according to J. Rosenau, the main factors determining the Russian foreign policy are idiosyncratic and role. Then he analyses the Russian documents of foreign policy, economic data and geopolitical ideas. On that ground, he makes a simple analyse using the neoclassical realism model, that's integrates Foreign Policy Analyse and International Relations Theory, joining independent and intervening variables, to support the article's hypotheses. That hypotheses say that, firstly, The Peoples Republic of China (PRC) plays a role of diversification of Russia's international economic ties; and secondly, The PRC status as a Russia's strategic partner is at issue, despite the official declarations of both sides.

Keywords: Russia, China, Russian foreign policy, Russian Chinese partnership, geopolitics

1 The publication was co-financed by a grant of Cracow University of Economics. 


\section{Китай как стратегический экономический партнер в концепциях внешней политики России в 2020-е годы}

\section{Аннотация}

В статье представлена идея возможного российско-китайского стратегического экономического партнерства в начале XXI века. С точки зрения неоклассического реализма автор указывает основные факторы, влияющие на внешнюю политику Российской Федерации в отношении Китая. Ссылаясь на мнение Дж. Розенау, автор считает, что главными определяющими российскую внешнюю политику являются факторы идиосинкразии и роли. Затем он анализирует российские документы внешней политики, экономические данные и геополитические идеи. На этом основании автор проводит простой анализ (используя модель неоклассического реализма, которая объединяет анализ внешней политики и теорию международных отношений), сопоставляя независимые и промежуточные переменные, чтобы подтвердить гипотезы статьи. Первая из них звучит: Китайская Народная Республика играет роль диверсификации международных экономических связей России. Суть второй гипотезы состоит в том, что статус КНР как стратегического партнера России остается под вопросом, несмотря на официальные заявления обеих сторон.

Ключевые слова: Россия, Китай, российская внешняя политика, российско-китайское партнерство, геополитика

\section{Introduction}

Since at least 2007, i.e., the famous critique of the West at the Munich peace conference by the Russian president Vladimir Putin, China has been emphasized as Russia's new strategic partner. These claims were significantly strengthened in 2014 following the deep crisis in Russian-Western relations, directly caused by the Russian annexation of Crimea and support for separatism in the eastern regions of Ukraine. Using an analytical model related to neoclassical realism, this article will attempt to verify to what extent the claims regarding the Eurasian turn in Russia’s foreign policy are true, and whether this maneuver is permanent.

The research questions to be verified are as follows:

- Is the People's Republic of China a diversification of the economic contacts of the Russian Federation? 
- Should the PRC be indeed treated as Russia's strategic partner, following the declarations by both parties?

\section{Theoretical and methodological assumptions}

To answer the research questions outlined above, the author will analyze the basic strategic documents of the Russian Federation, the economic ties as well as the geopolitical ideas, e.g., foreign policy goals defined in Russian geopolitics.

The tool for examining the issue of Russia's strategic partnership with China is the Foreign Policy Analysis and neoclassical realism. The author proposes an eclectic combination of these research programs. The advantages of such an approach were presented in the publications by, e.g., R. Sil and P.J. Katzenstein (2010, p. 9). The research tool, i.e., a combined model of these two programs is presented below. The model assumes that pressures from the international system, such as the distribution of capabilities, are transmitted by the internal national level (primarily state institutions). They are then processed and, based on this perception, solutions in the form of a specific foreign policy are developed. As stated by M. Kozub-Karkut (2020, p. 227-228), neoclassical realism wants to overcome the weaknesses of neorealism, which operates only at the level of the international system. It positions itself as a link between theories of international relations and of foreign policy. Therefore, the author found it an interesting theoretical proposition for the analysis of the research problem.

The set of factors that are considered important for the study of Russia's declared strategic partnership with China was derived from the model presented above. As independent variables, these would be the pressures of the international system, such as the economic positions of the actors, the political balance of power. The study also focused on the domestic level, i.e., primarily the perception of Russia's international challenges among the decision-making and advisory elites, and the importance of political ideas. Hence, the study covers the more important works of Russian geopoliticians influencing the discourse on Russia's foreign policy.

The catalog of presented factors does not indicate which of them are the most important for the ultimate shaping of political decisions. As early 


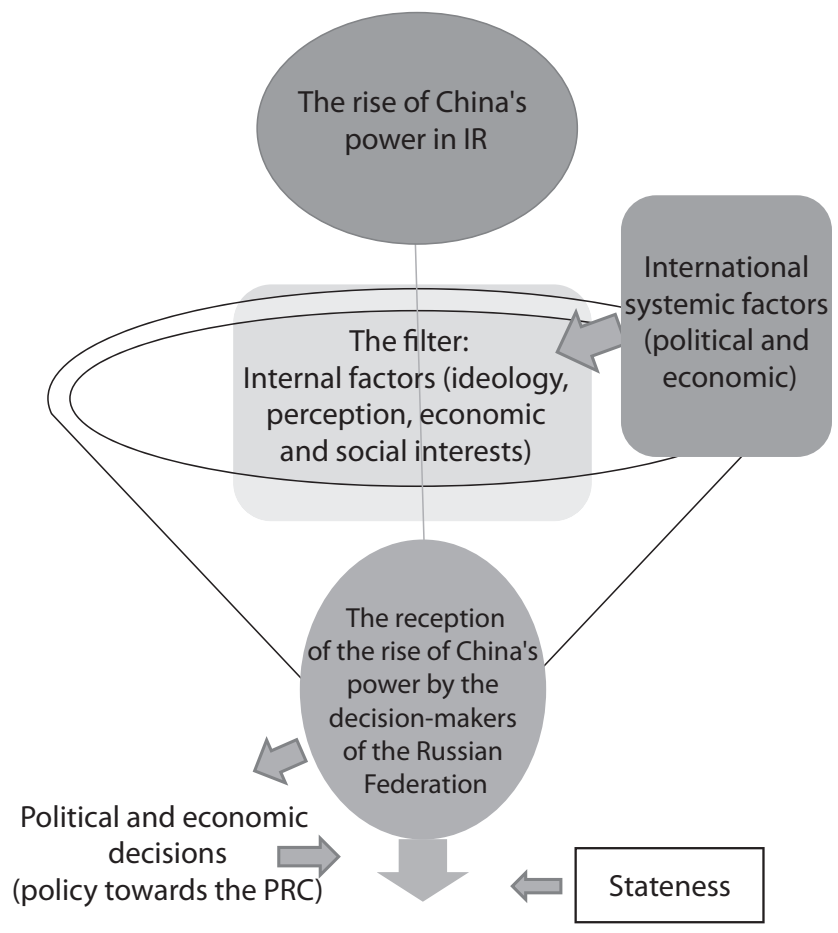

Figure 1. "Filtering" of pressure from the international system level in the political system (decision-making center) of the Russian Federation

Source: Own elaboration based on Blanchard, Ripsman, 2013, p. 33-34; Toje, Kunz, 2012, p. 5.

as in the 1960s, J. Rosenau (1966, p. 43-48) shed more light on the issue of factors that shape foreign policy, which can be used for modeling. He listed 5 groups of factors:

- Idiosyncratic,

- Role,

- Governmental,

- Societal,

- Systemic.

According to Rosenau, the greatest research challenge is the proper definition of the hierarchy of these factors within the foreign policy of individual 
countries. He also proposed a matrix of such a hierarchy addressed to specific types of countries. Among large countries with relatively little openness to international cooperation, the hierarchy of factors in contemporary Russia looks as follows: 1. Role, 2. Idiosyncratic, 3. Governmental, 4. Systemic, 5. Societal. Therefore, this systematics indicates that in matters of Russia's foreign policy, including its policy towards China, the country's aspirations to play certain roles in international relations are of particular importance, as is precisely described in K.J. Holsti's theory of roles. He listed examples of such attitudes, e.g., a regional leader, an anti-imperialist agent, isolationist, or independent actor, which seem to be important from Russia's perspective (Holsti, 1970, 260-270). Ideological factors are essential (especially geopolitics, in terms of Russia's foreign policy), as are the determinants of the political system in Russia, e.g., the importance of the presidential center and its public support. Additionally noteworthy are the systemic issues, i.e., certain international pressures. The issues of social impact on Russia's foreign policy come last. This can be justified by the problems of the development of democracy in Russia, and thus the significance of the society's possible influence on the government's actions. For many, Rosenau's research systematics has become key to understanding the importance of particular factors in foreign policy. As T. Pugacewicz pointed out (2019, p. 71), this systematics, followed by empirical research, has led to the detection of regularities in the behavior of states. H. Starr (1988, p. 8-10) pointed out that Rosenau opened a discussion on the importance of interactions between various levels of research on foreign policy (from local to national to international), along with the mutual determinants of these levels (e.g., the importance of economic ties). This point of view can be described as a starting point for research eclecticism and an inter-paradigmatic approach adopted in this article. Due to the scope limitations, this publication will focus only on the two most important factors influencing Russia's perception of China as a possible strategic partner, i.e., the international roles and idiosyncratic factors. In the subsequent stages of the development of the science of international relations, these two issues took the form of separate theories, the above-mentioned theory of international roles, and constructivism. The importance of these factors is reflected in the analysis of documents related to Russia's foreign policy and the work of Russian geopoliticians. The author also recognizes that the remaining factors 
shaping the Russian foreign policy can be reduced to the theses on Russian authoritarianism and the domination of Putin's vision of the organization and functioning of the state, which is often found in the literature on the subject, strengthened by tendencies towards external and internal autarky.

Table 1. A set of factors shaping Russia's policy towards China according to the model of neoclassical realism

\begin{tabular}{|l|l|l|}
\hline $\begin{array}{l}\text { Independent variable - the } \\
\text { international system (X) }\end{array}$ & Intervening variables $(\mathrm{Z})$ & Dependent variable (Y) \\
\hline $\begin{array}{l}\text { System structure and } \\
\text { capacity distribution. } \\
\begin{array}{l}\text { Indicators: GDP, foreign } \\
\text { trade indicators, invest- } \\
\text { ment shares. }\end{array}\end{array}$ & $\begin{array}{l}\text { e.g., national concepts of the Russian } \\
\text { foreign policy, internal influence of } \\
\text { the political system (ideas, influence } \\
\text { groups) }\end{array}$ & $\begin{array}{l}\text { Decision regarding } \\
\text { partnership with China }\end{array}$ \\
\hline
\end{tabular}

$\mathrm{X}$ - Independent variable - the international system (e.g., actors and their position in the international system)

$\mathrm{Z}$ - Intervening variable (the national level, a streamline to transmit structural pressure and develop solutions, e.g., interests of influence groups in the context of relations with decision factors)

$\mathrm{Y}$ - Dependent variable (a product reflecting the concept of relations with the PRC, or its output as an element of Russia's policy towards Asian countries).

Source: Own elaboration based on: Toje, Kunz, 2012, p. 5; Larsen, 2019; Kunz, Saltzman, 2012, p. 96-111; Ripsman, Taliaferro, Lobell 2016, p. 100-104; Taliaferro, 2009, p. 214.

\section{The structure of the system and the distribution of Russia's economic capacity in relation to China}

The analysis of individual versions of the Concept of Foreign Policy of the Russian Federation shows that Russia's primary goal is to maintain its superpower status and strategic balance between the main actors in the international arena. These political goals go hand in hand with economic goals, 
because in the $21^{\text {st }}$ century an increasing dominance of China in Russian economic relations can be observed. A brief look at these issues will allow a better understanding of the motives behind the development of certain spheres of relations with China, e.g., energy ties, and the attempts to limit others, e.g., the import of goods from China.

According to the data provided by Gazprom, Europe accounts for approx. $80 \%$ of Russian gas exports outside the former USSR. In 2019, Gazprom exported 234 billion cubic meters of gas outside the former USSR area, including 199 billion cubic meters to Europe (Gazprom, 2019). At the same time, about 1.5 billion cubic meters of Russian gas were delivered to China. Additionally, more than 5 billion cubic meters of LNG were delivered to the countries of East Asia (Gazprom, 219a). Russia's dependence on the European gas market is well illustrated by the map of Gazprom's infrastructure connections, which clearly shows that the network is focused on cooperation with the West.

If the development of energy ties with China is a diversification of cooperation with Europe, then in trade cooperation a clear increase in the importance of China every year can be observed (see Figures 1 and 2). China won a dominant position in Russian imports of goods as early as 2008 and became its most important partner in 2014.

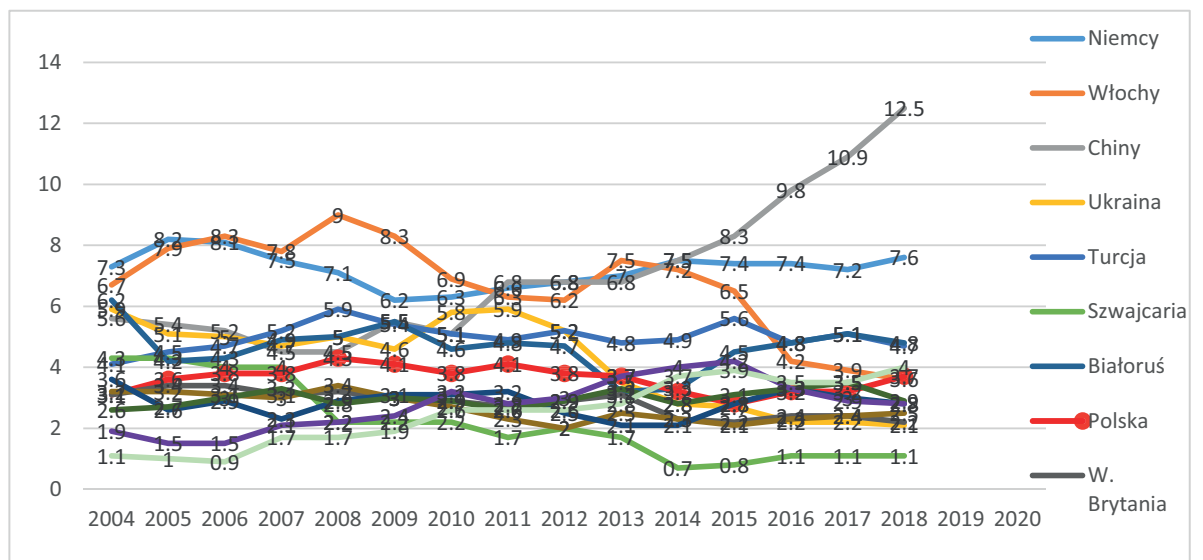

Graph 1. Russia's main partners - Russian exports

Source: own study based on ROSSTAT and www.trademap.org. 

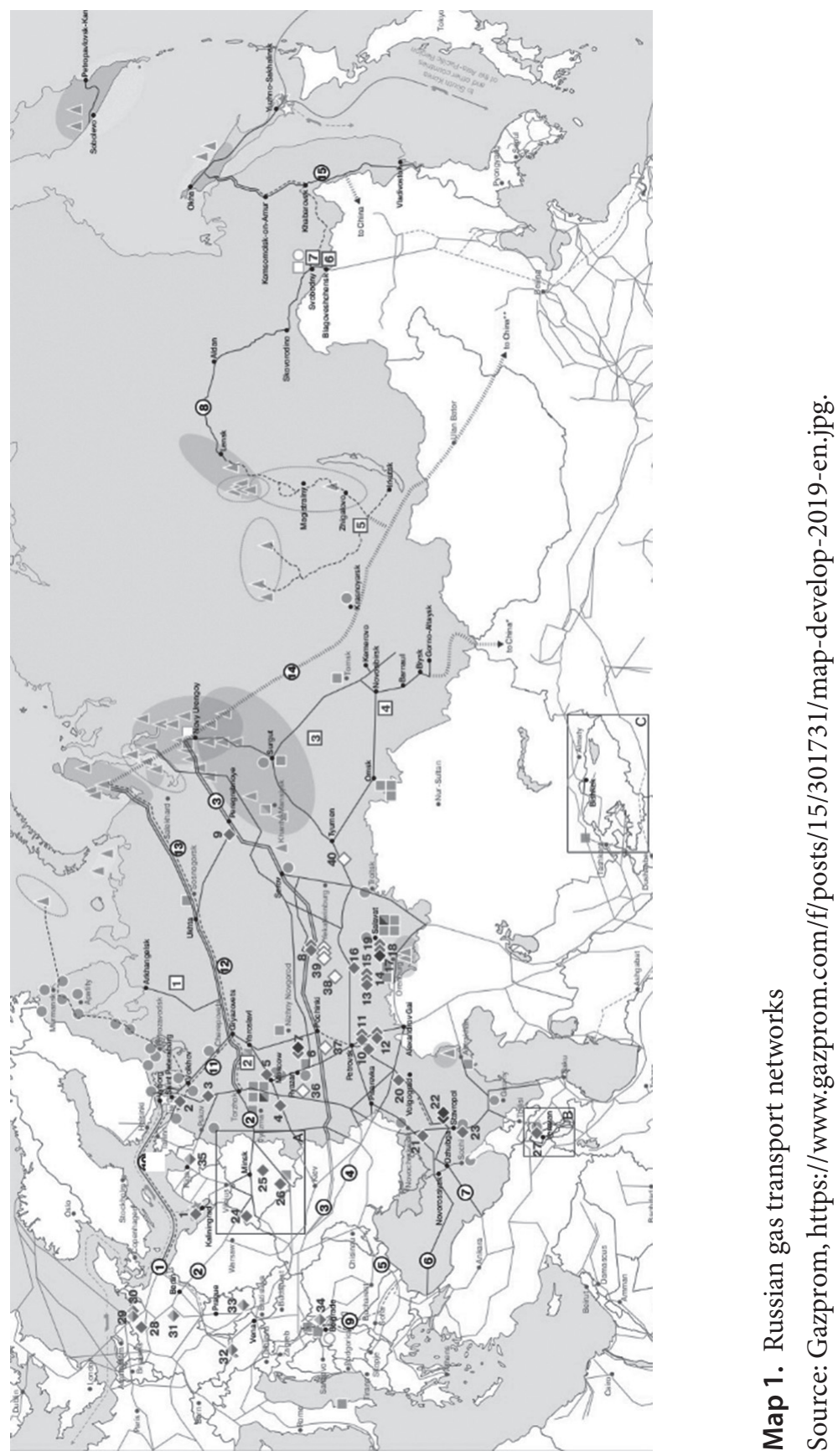


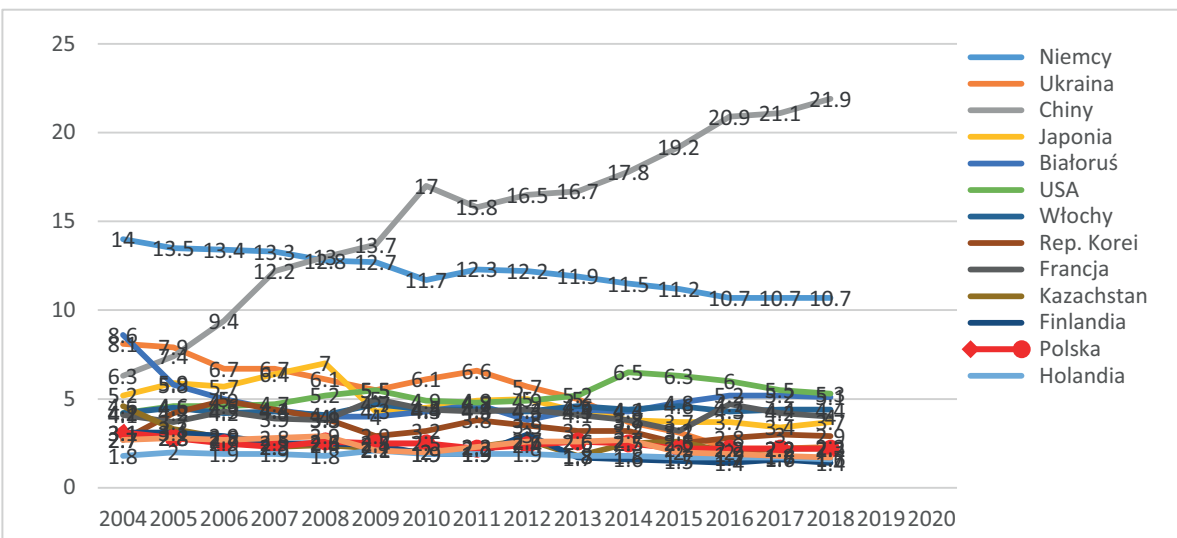

Graph 2. Russian Federation's main import partners

Source: own study based on ROSSTAT and www.trademap.org.

Tables 2 and 3 show the flows of direct investments between Russia and China. Russian investments in China are not significant in value. Since 2009, there has been a significant revival in the flow of direct investment from China to Russia, which may confirm the thesis regarding an increase in this type of cooperation. At the same time, it can be seen that the Western countries (mainly Germany) were the more serious and stable partners.

Table 2. Foreign direct investments in Russia (in USD million)

\begin{tabular}{|c|c|c|c|c|c|c|c|c|c|c|c|c|c|c|c|c|}
\hline & ठ্ণ & 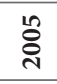 & 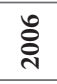 & હ્ટે & 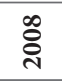 & ڤ્ટે & 을 & $\overline{\bar{\Xi}}$ & ב) & $\stackrel{m}{\stackrel{n}{n}}$ & 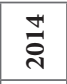 & 登 & 룰 & 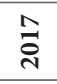 & 㒸 & )े \\
\hline & & 21 & 46 & 526 & 379 & 2914 & 3196 & 34 & 2265 & 335 & 349 & 483 & 224 & 0 & 1 & 46 \\
\hline . & & 230 & 283 & 1860 & 161 & 96 & 435 & 276 & & 485 & & 209 & 2 & 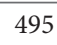 & 76 & -105 \\
\hline & & & OQ & 112 & 9 & 231 & 336 & & 450 & 97 & 1271 & 645 & J & 140 & 13 & \\
\hline
\end{tabular}

Source: CBR, https://www.cbr.ru/statistics/macro_itm/svs/ (3.07.2020); Россия и страны мира - 2010 г., https://gks.ru/bgd/regl/B10_39/Main.htm.

Table 3. Direct investments from the Russian Federation (USD million)

\begin{tabular}{|c|c|c|c|c|c|c|c|c|c|c|c|c|c|c|c|c|}
\hline & ఫัे & 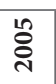 & 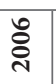 & $\hat{\stackrel{्}{े}}$ & ڤั̀ & ठ્ণે & 올 & $\overline{\text { ปे }}$ & ָ̃ & M্ & ذ্ं & 옥 & ֻั & $\hat{\vec{n}}$ & $\stackrel{\infty}{\grave{d}}$ & $\hat{\bar{ก}}$ \\
\hline Germany & 0.0 & 21 & 137 & 673 & 1860 & 1488 & 1880 & 971 & 1118 & 1334 & 1016 & 738 & 393 & 724 & 1078 & 1455 \\
\hline USA & 276 & 115 & 192 & 973 & 7264 & 1634 & 1060 & 1625 & 688 & 739 & 1654 & 819 & 873 & 126 & 653 & \begin{tabular}{|l|}
-580 \\
\end{tabular} \\
\hline China & & & t & 48 & 25 & 22 & 30 & 20 & 63 & 14 & 54 & 11 & 6 & 33 & 35 & 43 \\
\hline
\end{tabular}

Source: CBR, https://www.cbr.ru/statistics/macro_itm/svs/ (3.07.2020); Россия и страны мира - 2010 г., https://gks.ru/bgd/regl/B10_39/Main.htm. 


\section{Partnership with China in strategic documents of the Russian Federation}

The analysis of official strategic documents is of great importance for understanding Russia's foreign policy priorities and the perception of the challenges that this country is facing, despite their declarative nature. Therefore, on the one hand, an assessment of the development of the international situation and the solutions proposed by the country (or rather its decision-making elite) can be observed, as well as the roles Russia would like to play in international relations.

When analyzing the documents regarding Russia's foreign policy, it is clear that the Russian Federation has been paying more and more attention to new, or potential world powers. At the same time, there is a clear evolution in Russia's international policy regarding declared cooperation with key regions. The author selected the 2008,2013, and 2016 versions of the Concept of Russia's Foreign Policy for the study.

In the 2008 Concept, Russia focused on balancing its international policy between various regions, primarily the Western world and Asia. The importance of alliances with key partners, such as G8, BRICS, leading EU countries, and the USA was also emphasized. This section also mentions the importance of relations with India and China. The document stressed that in Asia, the most important thing for the Russian Federation is the development of friendly relations with China and India. A Russian-Chinese strategic partnership will be established in all areas, as one of the basic elements of regional and global stability, based on an analysis of their importance for Russia's national interests. The main task in the area of bilateral relations is to develop a high level of economic relations, similar to that of political relations. Despite emphasizing Russian interests with the CIS and Asian countries, the idea of a single space from Vancouver to Vladivostok was vivid in this document (Концепция..., 2008). This concept was in line with the so-called Medvedev's plan, which was a proposal to divide the spheres of influence between Russia and the West, to regulate relations in the Eurasian area.

In the 2008 Concept, despite the declaration on strategic partnership, China was treated on an equal footing with India and included in a broad vision of Russia's global policy with many centers of influence. 
In the 2013 Concept, the foreign policy authors emphasized several new challenges for the policy of the Russian Federation. Despite criticism from the West, it offers to regulate the strategic partnership with the West and to counteract common threats. In the context of the presented considerations, the document indicated, e.g., a change in the balance of international forces caused by the weakening of the Western world and the growing power of Asian states. This concept clearly states that the process of declining opportunities and historical significance of the West in favor of the Asia-Pacific area is deepening (Концепция..., 2013). S. Bieleń (2014, p. 143) even proposed that Russia "lost the modernization impulses coming from the West, which was undergoing serious economic perturbations". In analyzing the 2013 concept, W. Rodkiewicz (2013) pointed out that it did not provide for fundamental changes in the priorities of Russian foreign policy. The most important of them was building a sphere of influence in the post-Soviet area, as in the previous editions of this document. However, this version more strongly emphasized the importance of regional integration, with the key role attributed to the Eurasian Economic Union. Compared to the previous version, the new provision of the concept was to prioritize relations with Western countries, emphasizing the civilizational community that binds Russia with them. Hence the offer of strategic partnership with the West, especially with the European Union. Rodkiewicz described the 2013 concept as "the offer to conclude a 'geopolitical' and 'geoeconomic' agreement on strategic cooperation between Russia and the Western world". The challenge that prompted him was, among others, the rise of the Asian powers. Please note that the 2013 concept was created in the conditions of increasing competition between the Russian Federation and the European Union for influence in the so-called Eastern Partnership countries, i.e. the six countries that constitute a buffer in the east between the EU and Russia. The rivalry culminated in Russia's intervention in Ukraine's internal affairs in 2014, followed by the annexation of Crimea. The indicated international background is extremely important because it shows that it is similar to the previous versions of the Concept. Partnership with China was a form of diversifying political and economic ties with the West.

In the 2016 Concept, a growing tendency to move away from priority relations with the West in favor of Asian countries can be observed. It 
mentions, e.g., shifting the global center of power and development to the Asia-Pacific area and at the same time ending the dominance of the West in global economic and political relations.

Political concepts, mainly balancing contacts with the West with relations with Asian countries, were supported by economic interests with Asian countries, also a form of diversification of economic ties with the West (Концепция..., 2016). As stated by A. Rahr (2012,p. 203-205), Russia feared neo-colonization on the part of Western countries, hence it was developing relations with the East. Therefore, the 2016 Concept offers provisions regarding Russia's alternative to partnership with the Euro-Atlantic region, and that new cooperation should be based on the agreement between the European Union and the Eurasian Economic Union. There was no longer any mention of Russia's strategic partnership with the EU. In the 2016 document, the Russian Federation withdrew from the 'priority nature' of the development of relations with the Euro-Atlantic region and of the 'strategic community of goals. There were also no statements regarding the common civilizational identity of Russia and the West (Концепция..., 2016). Experts of the Centre for Eastern Studies called such declarations 'the Asian turn scare', because the main goal of the Concept was to convince the West to make concessions that would enable the end of the conflict with Russia on its terms and the normalization of mutual relations (Rodkiewicz, 2016).

In the 2016 Concept, the role of BRICS and China in the management of international order was outlined. Strategic partnership with China was indicated, but only after mentioning the importance of contacts with the CIS, ODKB, SCO, EU, NATO and ASEAN. There was a clear emphasis on the importance of the post-Soviet region for the Russian Federation. China's special place in Russian politics was mentioned, but at the same time the importance of relations with other Asian countries was emphasized, e.g., India (second after China, but its position was clearly strengthened) and Japan (no information on disputes with this country were mentioned) as well as organizations, such as ASEAN (Концепция..., 2016). Interestingly, a similar dynamic of priorities can be observed in the publications of Russian geopoliticians, as described below. Experts of the Centre for Eastern Studies considered such a systematic approach to the importance of individual countries in Russia's foreign policy as a clear attempt to diversify the 
international contacts of the Russian Federation. The analysts pointed out that when the nature of relations with India was strengthened by terms of 'historic friendship' and 'deep mutual trust', relations with China were defined solely in terms of convergent interests. The provisions of the Concept indeed reflect the growing importance of China as Russia's most important partner on the international arena, however the statements used in the document suggested, e.g., lack of confidence in relations with Beijing. The purpose of such provisions could be to signal to the West, China and other Asian partners that Russia is striving to balance relations with Beijing (Rodkiewicz, 2016). Therefore, especially in the 2016 Concept, Russia's fear of becoming dependent on a Chinese partner can be observed, as indicated by in his publication by M. Lubina (2014, p. 536-537).

Since 2014, Russian-Chinese relations have intensified, as indicated by the official visit of Russian President Putin to China in 2014, during which he signed 46 documents on the development of relations with the People's Republic of China. The agreements covered the entire spectrum of issues, from cross-border cooperation, to declarations of cooperation in the international arena, to military, nuclear and economic cooperation (power production, trade, investments, infrastructure etc.) (Документы..., 2014). Two issues in Russia's relations with China seemed to be fundamental: economic cooperation and international issues (mainly balancing the US position) ( $O$ российко-китайских...). This direction was especially observable in the context of tensions with the West following the events in Ukraine in 2014. On the other hand, as has already mentioned, Russia has tried to maintain a balance in relations with China by diversifying it by developing relations with other partners.

\section{Geopolitical ideas}

In this part, the author will briefly present the results of own research of the texts of leading Russian geopoliticians, who shape the country's geopolitical discourse and have a great influence on the political elite, especially in view of the popularity of geopolitics in Russia.

In the pro-Western geopolitical current the authors were generally skeptical as to the strategic partnership with China. In their visions, the 
modernization and development of Russia should occur thanks to the West and its models. D. Trenin (2007, p. 34) even pointed out to the need to westernize Russia. Trenin criticized, e.g., the policy of rapprochement with China, considering it to be wrong. He pointed out that if the Russian authorities wanted to achieve their strategic goal in Asia, i.e. the modernization and development of the Russian Far East, then the key partner should be Tokyo instead of Beijing. This is due to Japan's economic potential and technological development necessary for the development of the Asian part of Russia (Trenin, 2007, p. 69-70). Therefore, Russia should modernize itself and, together with its Western partners, stabilize and modernize the post-Soviet region. If Russia does not follow this path of change, one part of the country will gravitate towards cooperation with Europe, and the other part will be influenced by China (Potulski, p. 16-17; Trenin, 2007, p. 14-15). Disappointed by the unsuccessful Western-style modernization and integration of Russia, Trenin (2019) warned against entering the sphere of Chinese influence. He encouraged balancing it with relations with other partners, such as Japan, which he described as a modern state with a strong economy and independent international politics. These statements are very interesting and conspicuously not stand-alone, because they also contained such theses, as shown in the analysis of documents on Russia's foreign policy.

A. Bogarutov, just like Trenin, pointed out that the West is a better development model for Russia. He apparently criticized the ideas of the Eurasians for their claim of the Russia-China alliance as a counterbalance for the power of the United States. He believed that such an arrangement was not rational for Russia. A. Bogaturov argued that it was difficult to present a better option against the liberalism promoted by the USA, its development patterns, vision of the world order and standards in politics (Богатуров, 2002, p. 287). In the following years, A. Bogaturov slightly revised his views on cooperation with the West. He also emphasized more clearly the importance of developing cooperation with the countries of East Asia, such as China and Central Asia. To Bogaturov, it could be an element in strengthening Russia's international position and its importance for other actors, including the West (Богатуров, 2010, p. 95). This brought the author closer to the majority of Russian geoeconomists who expressed the need to diversify Russia's international ties. Analyzing the A. Bogaturow ideas, A. and P. Cygankow (2017, p. 175) 
emphasized that Bogaturow, as the founder of the school of international relations known as enlightened statism, emphasized the importance of the internal development of the Russian Federation. He tried to combine the ideals of a strong, independent state with the individual rights. A. Bogaturov was trying to skilfully combine his ideas of Russia's place in the international system with the need for a flexible strategy while maintaining an active dialogue with the West, so China would only be an element balancing relations with the Euro-Atlantic region.

Evolution of geopolitical views can be observed in another Russian author, S. Karaganov. The once pragmatic Atlantist, very close to the decision-making circles of the Russian Federation, began to criticize relations with the West in early $21^{\text {st }}$ century. He claimed that Europe is plunging into economic and civilizational stagnation, therefore Asian countries are becoming a new center of modernization for Russia. Karaganov (2018) argued that the time had come to develop relations with Asia, especially since Europe itself turned its back on Russia through sanctions: "We owe a lot to Europeans, their example has made us a world power, a culture of global importance. But today the wave of modernization comes from the East".

Eurasianism - this current clearly emphasizes the Eurasian character of Russia and the need for cooperation with Asian countries, including China. It is impossible to fully present the claims of this trend regarding a possible strategic partnership with China, which is why this article will focus only on the latest conclusions from authors who began to clearly emphasize the need to preserve Russia's independence in contacts with China. G. Ziuganow and A. Dugin, who combined political activity with an attempt to build a coherent doctrine of neo-Eurasianism (Potulski, 2010, p. 119-120) seem the most famous and representative figures for understanding the geostrategic concept of Russia's development in Eurasian thought. Also noteworthy is a former candidate for the presidency of Russia and then Putin's advisor S. Głaziew, a geoeconomist and follower of this current.

A. Dugin (2014, p. 118-119) argued that Russia's only way to remain relevant in history is to build an alliance with Eurasian powers with enormous demographic, economic, military and cultural potential. In his opinion, Russia's great geopolitical project should assume the revitalization of Moscow's relations with Berlin, Teheran, Delhi, Beijing and Tokyo. The process 
of building close ties with Asian powers was to make the West realize that its aspirations as the global leader were not accepted not only by Russia, but also by other world powers. That is why A. Dugin also proposed the idea of a multipolar world whose economic basis was to restrain Western capitalism. In this regard, Dugin referred to Marxism and neo-Marxism, explaining the differences of interests between Western countries and the developing economies of Eurasian countries. Eurasian countries should reject the economic hegemony of the West, building their own economic systems that would reflect their character and interests (Дугин, 2013, p. 188-190, 192-194). The countries of the East should therefore build their own economic systems, independent of the West, with their own currencies. These systems should be pluralistic, without a single dominant universal pattern. A. Dugin (2011, p. 494) paid special attention to India and China as they could play an important role in Russian geopolitical projects because of their economic potential. China which became a competitor of the United States due to its development and economic importance, seemed the most interesting for the author. A. Dugin (2014, pp. 250-251) also believed that Putin's geopolitical vision and political practice corresponded to the assumptions of Eurasianism and the idea of multipolarity, as it was the only possible and rational vision of politics for Russia. The foundation for this project was the long-term economic partnership of Eurasian countries for the purposes of mutual strategic development. G. Ziuganow, the leader of the Communist Party of the Russian Federation, but also a scientist, argued that Russia should concentrate on rebuilding its economic and military power, and not be drawn into a confrontation with China and the Islamic world (Potulski, 2010, p. 121-122). He was critical of cooperation with the West and open to Asian countries, including China.

Russian geoeconomists in the Eurasian current, such as S. Glaziew, emphasized the importance of the alliance between Russia and China to "neutralize American aggression" (Глазьев, 2018, p. 30). However, the US-provoked war against Russia could also prove profitable for China because the mutual weakening of the USA, the EU, and Russia, with China's neutrality, could have been a positive thing for Beijing, enabling it to achieve the position of a world leader (Глазьев, 2018, p. 301). S. Głaziew stated that among the geopolitical strategies for Russia, the variant of the 
Russian-Chinese strategic partnership is the most likely and feasible. It was to be guided by joint Eurasian integration projects. An element of this strategy should also be a broad anti-war coalition with India. This strategy would force a change in American policy and lead to the most desirable and beneficial variant of global relations: a partnership between the USA, Russia, and China in the future, to jointly manage global security and peace (Глазьев, 2018, p. 261).

Eurasianism rejected both the unipolar world and isolationism. Russia should find allies against US domination in the East and West. Russia's chance to be listed as one of the great powers is to help other countries: the EU, China, India, the Islamic world, and the CIS countries become superpowers, but on terms that are favourable to Russia. Instead of shunning globalization, it would be giving it a radically different vector: Eurasian instead of Atlantic (Вартанян, 2007, p. 156-157).

Isolationism - this current focuses on the autarky and independence of Russia. It is distanced from all strategic partnerships unless treated only as tactical solutions. Isolationism emphasizes that in Russia there is no basis for the development of the economy and statehood modeled on the traditions of Western European liberalism, and that competition, individualism, and lack of state intervention in the economy were contrary to the Russian tradition. In the west, the geopolitical challenge for Russia was the western geocivilization, in the east - the Confucian-Buddhist and Japanese geocivilization, and in the south - the Muslim geocivilization. Thus, Russia was under military, economic, cultural, and commercial pressure, as well as other forms of geocivilizational expansion (Potulski 2010, p. 221-224). Russia should influence its environment through its attractiveness. However, the most important thing was the country's internal socio-economic, development, because the challenge for Russia was the geopolitical influence of the West and China (Цыганков 2015, p. 13-14). W. Cymburski, the author of this current, also referred to the idea of multipolarity. Its foundation would also be geoeconomic determinants enabling the creation of a geopolitical pole with the center in Russia, which will extend between the region of East Asia and Europe. The geopolitical pole would simultaneously be independent of the West and the East, and at the same time, it would act as an intermediary in the cooperation between Asia and Europe (Potulski, 2010, p. 148-150). 
A large group of Russian analysts and scientists dealing with geopolitics seemed to share Cymburski's sentiments. They emphasized that Russia should remain independent from the West (USA) and Asia (China), because both geopolitical poles may seek to subjugate Russia (Пантин, 2009, p. 177-178).

S. Kisieliew $(2017$, p. 6,11$)$ pointed to the threat of NATO expansion as a powerful military and political tool in Western countries. The author emphasized that NATO's expansion was accompanied by ideological expansion expressed as the promotion of the Western civilization ideas, including economic ones. That is why Kisielew also emphasized the importance of Eurasian integration, e.g., within the framework of the Shanghai Cooperation Organization, which would unite the potentials of the Eastern countries (also economic), contribute to the economic development of these countries, and balance the expansion of the West. Similarly, the author looked at the problem of the growth of Asian powers, pointing to, e.g., the high rate of economic growth of these countries, the development of the population, or military expenditure, which were also a challenge for Russia (Kiselev, 2002, 221-225).

Russian geoeconomists emphasized that an important challenge was the diversification of the Russian economy and international economic contacts. Therefore, they feared excessive dependence on the economic powers of the East (such as China) and the West (USA) (Анохин, Лачининский, 2014, p. 72). The geoeconomist A. Nekless (2009, p. 44) saw Russia's challenges similarly. He placed the country in the economic area between the West and the New North (dominated by China) and the New South, which caused serious development challenges for Russia.

\section{Conclusion}

Analysis of individual versions of the Concept of the Foreign Policy of the Russian Federation leads to the conclusion that Russia's goal is to maintain the status of an independent actor in international relations. The declared partnership with China is treated as an element of balance in Russia's international relations. At the same time, this partnership is noticeably quite forced by the development of the PRC's power. Upon analyzing Russia's economic ties, it can be observed that indeed such pressure in the economic sphere on the part of Beijing is very clear. We can therefore presume that despite official 
declarations by the Russian authorities and even geopoliticians regarding the strategic partnership, Russia treats China's growth as a challenge to own position. The Russian concept of a multipolar world is therefore aimed at minimizing the country's challenges stemming from geopolitical changes: the weakening position of the West and the growing power of China.

The review of Russian geopolitical trends also indicates that even the trends postulating the development of Russia as a Eurasian power and a close partnership with China indicate that this cooperation must take place on an equal basis, balanced by cooperation with other countries, be it Asian or Western. Therefore, China is not indicated as the only and exclusive strategic partner, but as a means of playing a superpower role for Russia, preferably in the US-Russia-China triangle.

Neoclassical realism, which was indicated as an interesting and decisive research approach, forces a combination of international and national factors to provide a comprehensive answer to the research questions. M. Kozub-Karkut (2020, p. 233-242) points out that this is one of the greatest challenges of neoclassical realism, which he considered an important research problem. However, Kozub-Karkut provides interesting tips, based on the relevant literature. Based on the analyzed issues, let us assume that the international pressure is the changes in the distribution of power in international relations, leading to the weakening of Russia's power position (an independent variable). To remedy this, Russia declares the adoption of certain steps (a dependent variable), resulting from the perception of international challenges (cognitive determinants, e.g., neo-Marxism, strongly present in Eurasianism), aspirations to play specific international roles, as well as rooted ideas (e.g., geopolitical). This simplified consideration yields an answer to the posed research questions, which makes the feasibility of the PRC's status as a strategic partner doubtful, despite such declarations. The PRC is treated in these strategies as an element of the diversification of economic and political contacts of the Russian Federation. At the same time, it is recognized that the PRC itself poses a very serious challenge to Russian foreign policy.

The dilemma of Russia's adequate policy towards China, especially when it comes to declarations, is also very well reflected in the theory of international roles. It points out that Russia is attempting to compete for 
the status of at least a regional leader, one of the leaders of the multipolar world. The Russian Federation is also trying to win over China by playing the role of an anti-imperial actor (and even a leader) especially concerning the United States. Interestingly, such an approach to Russia's international roles is reflected on many analytical levels, as pointed out by authors associated with this theory, such as K.J. Holsti, S.G. Walker, M. Breuning (Thies, 2017). This multilevel role is reflected in particular in geopolitical ideas promoted by leading Russian geopoliticians, but also in the doctrinal layer. It reflects the Russian Federation's political and advisory elites' aspirations to play international roles, motivated by neo-imperial social expectations.

Of course, a full analysis of the outlined problem deserves a more indepth study in the form of a monograph.

\section{DR. RAFAŁ LISIAKIEWICZ}

Department of Political Studies

Cracow University of Economics

Rakowicka 27, 31-510 Kraków

rafal.lisiakiewicz@uek.krakow.pl

\section{Bibliography}

Bieleń, S. (2014), Meandry modernizacyjne Rosji. In: J. Diec, A. Jach (ed.), Fenomen Rosji. Pamięć przeszłości i perspektywy rozwoju. Część 2: Kontekst polityczny i gospodarczy. Krakow: Księgarnia Akademicka.

Blanchard, J.M.F., Ripsman N.M. (2013). Economic Statecraft and Foreign Policy. Sanctions, incentives, and target state calculations. London: Routledge.

Dugin, A. (2014). Putin vs Putin. Vladimir Putin Viewed From The Right. Budapest: ARKTOS.

Gazprom 2019. Retrieved from: https://www.gazprom.com/about/marketing/europe/. Gazprom 2019a. Retrieved from: https://www.gazprom.com/about/marketing/.

Holsti, K.J. (1970). National Role Conceptions in the Study of Foreign Policy. International Studies Quarterly, 14(3), 233-309.

Kozub-Karkut, M. (2020), Realizm neoklasyczny w perspektywie teorii stosunków międzynarodowych i polityki zagranicznej. Krakow: Wydawnictwo Uniwersytetu Jagiellońskiego.

Kunz, B., Saltzman, I.Z. (2012). External and domestic determinants of state behaviour. 
In: A. Toje, B. Kunz (ed.), Neoclassical realism in Europe. Bringing power back in. Manchester: Manchester University Press.

Larsen, H.B.L. (2019). NATO's Democratic Retrenchment. Hegemony After the Return of History. London, New York: Routledge.

Lubina, M. (2014). Niedźwiedź w cieniu smoka. Rosja-Chiny 1991-2014. Krakow: Księgarnia Akademicka.

Marszałek-Kawa, J. (red.). (2010). Chiny supermocarstwem XXI wieku? Rozważania na temat polityki i gospodarki Państwa Środka. Toruń: Wydawnictwo Adam Marszałek.

Marszałek-Kawa, J. (red.). (2014). Globalna polityka Chin. Czynniki i perspektywy. Toruń: Wydawnictwo Adam Marszałek.

Marszałek-Kawa, J., Dmochowski, T. (red.). (2018). Rozważania o kierunkach współczesnej polityki Chin. Toruń: Wydawnictwo Adam Marszałek.

Potulski, J. (2010). Współczesne kierunki rosyjskiej myśli geopolitycznej. Między nauką, ideologicznym dyskursem a praktyką. Gdansk: Wydawnictwo Uniwersytetu Gdańskiego.

Pugacewicz, T. (2019). Studia nad polityką zagraniczną z poziomu czynników krajowych. Historia rozwoju i współczesne wyzwania w nauce światowej i polskiej. Stosunki Międzynarodowe - International Relations, 1(55), 59-86.

Ripsman, N.M., Taliaferro, J.W., Lobell, S.E. (2016). Neoclassical Realist Theory of International Politics. Oxford: Oxford University Press.

Rodkiewicz, W. (2013, 20 February). Koncepcja polityki zagranicznej Federacji Rosyjskiej. Analizy OSW. Retrieved from: https://www.osw.waw.pl/pl/publikacje/ analizy/2013-02-20/koncepcja-polityki-zagranicznej-federacji-rosyjskiej.

Rodkiewicz, W. (2016, 7 December). Straszenie zwrotem ku Azji - nowa Koncepcja polityki zagranicznej Rosji. Analizy OSW. Retrieved from: https:// www.osw.waw.pl/pl/publikacje/analizy/2016-12-07/straszenie-zwrotem-ku -azji-nowa-koncepcja-polityki-zagranicznej-rosji.

Rosenau, J.N. (1966). Pre-theories and theories of foreign Policy. In: F.R. Barry (ed.), Approaches in Comparative and International Politics. Evanston: Northwestern University Press.

Sil, R., Katzenstein, P.J. (2010). Beyond paradigms: analytic eclecticism in the study of world politics. Houndmills, Basingstoke, Hampshire, New York: Palgrave Macmillan.

Starr, H. (1988). Rosenau, Pre-theories and the Evolution of the Comparative Study of Foreign Policy. International Interactions, 14(1), 3-15.

Taliaferro, J.W. (2009). Neoclassical realism and resource extraction: State building for future war. In: W. Taliaferro, S.E. Lobell, N.M. Ripsman (ed.), Neoclassical Realism, the State, and Foreign Policy. Cambridge: Cambridge University Press.

Thies, C. (2017). Role Theory and Foreign Policy. In: Oxford Research Encyclopaedia. Retrieved from: https://oxfordre.com/internationalstudies/view/10.1093/ acrefore/9780190846626.001.0001/acrefore-9780190846626-e-291.

Toje, A., Kunz, B. (2012). Introduction: neoclassical realism in Europe. In: A. Toje, B. Kunz (ed.) Neoclassical realism in Europe. Bringing power back in. Manchester: Manchester University Press.

Trenin, D. (2007). Getting Russia right. Washington, DC: Carnegie Endowment for Int'l Peace. 
Trenin, D. (2019, 25 April). It's Time to Rethink Russia's Foreign Policy Strategy. Carnegie Moscow Center. Retrieved from: https://carnegie.ru/commentary/78990.

Анохин, А.А., Лачининский, С.С. (2014). Эволюция идей и содержания геоэкономических исследований. Известия Русского Географического Общества, 146(2), $66-76$.

Богатуров, А.Д., Дундич, А.С., Троицкий, Е.Ф. (2010). Центральная Азия: «отложенный нейтралитет» и международные отночения в $2000 x$ годах. Очерки текущей политики . Выпуск 4. Москва: НОФМО.

Богатуров, А.Д. (2002). Плюралистическая однополярность. In: А.Д. Богатуров, Н.А. Косолапов, М.А. Хрусталев (ed.), Очерки теории и политического анализа международньх отношений. Москва: Научно-образовательный форум по международным отношениям.

Вартанян, Р.Г. (2007). Россия, Европейский Союз и страны Кавказа: новые горизонты сотрудничества в ХХІ веке. Москва: Социально-политическая МЫСЛЬ.

Глазьев, С. (2018). Рьвок в будущее. Россия в новых технологическом и мирохозяйственном укладах. Москва: Книжный мир.

Документы подписанные в рамках официального визита Президента Российской Федерации В.В. Путина в Китайскую Народную Республику (2014, 20 Мау). Президент России. Retrieved from: http://kremlin.ru/supplement/1643.

Дугин, А. (2011). Геополитика. Москва: Академический проект.

Дугин,А. (2013). Теория Многополярного Мира. Москва: Академический проект.

Караганов, С. (2018). Европа геостратегически оголена и в одиночку нежизнеспособна.PortalРоссияв ВлобальнойПолитике.Retrieved from:https://globalaffairs.ru/ pubcol/Evropa-geostrategicheski-ogolena-i-v-odinochku-nezhiznesposobna19882.

Киселев, С.Г. (2002). Основной инстинкт изивилизаций и геополитические вызовы России, Москва: Известия.

Киселев, С.Г. (2017). Еврацийское пространство - арена глобального противостояния. In: С.Г. Киселев (ed.), Россия и евразийское пространство: векторы развития: коллективная монография. Москва: МАКС Пресс.

Концепция внешней политики Российской Федерации (2008, 15 July). Президент Poсcuu. Retrieved from: http://kremlin.ru/acts/news/785.

Концепция внешней политики Российской Федерации (утверждена Президентом Российской Федерации В.В. Путиным 30 ноября 2016 г.). МИД. Retrieved from: https://www.mid.ru/ru/foreign_policy/official_documents/-/asset_publisher/ CptICkB6BZ29/content/id/2542248.

Неклесса, А.И. (2009). Геоэкономическая формула мироустройства. Траектории России в новом универсуме. In: Геоэкономическая формула мироустройства: Россия в новом универсуме. Материалы научного семинара. Выпуск № 1. Москва: Научныйэксперт.

Пантин, В.И. (2009). Мировые циклы и перспективы России в первой половине ХХІ века: Основные вызовы и возможные ответы. Дубна: Феникс+.

О российско-китайских отношениях стратегического партнерства (2017). МИД. Retrieved from: http://www.mid.ru/strategiceskoe-partnerstvo-s-kitaem. 
Рар, А. (2012). Куда пойдет Путин?Россия между Китаем и Европой. Москва. Цыганков, А.П. (2015). «Островная» геополитика Вадима Цымбурского. Тетради по консерватизму, 1, 12-20.

Цыганков, А.П., Цыганков, П.А. (2017). Просвещенное державничество (А.Д.Богатуров и российская теория международных отношений). «Полис», 4, 175-185. 